\title{
The impact of pro-russian public organizations and parties on the annexation of the Crimea by the Russian Federation
}

\begin{abstract}
A crucial role in the annexation of the Crimean peninsula by the Russian Federation was played by pro-Russian parties and movements that had been established with the Kremlin's intelligence agencies, having been financially supported for more than twenty years. On the territory of the Crimea, where the Kremlin authorities created a network of agents, the role of subversion is the most obviously tracked, being a significant segment of Russian policy. A propaganda component proved to be the key in the Russian incorporation of the Crimea, not being an addition to armed aggression, but an independent element of the hybrid war against Ukraine, and the information and psychological influence of Moscow through the media and the Internet on the population both in Ukraine and, in fact, in Russia, was unprecedented for the entire post-Soviet era.

The objective of the author is to reveal the courses of action of the pro-Russian parties and organizations in the interests of a foreign state, the psychological and informational effect on the Crimean audience during the latent phase of annexation, and the socalled "Crimean Spring". Despite the contemporary nature of the issue, there is a lack of relevant detailed research on this theme. Scientific exploration dedicated to the prognostication of events related to the implementation of hybrid war techniques and the analysis of the media security and counteraction to information and psychological operations, mainly consider both the social and political aspects of the propaganda impact. Beyond the attention of the study there is a public factor that highlights the propaganda methods applied in conditions of hybrid warfare.

The scientific novelty of the paper is to conduct a study of the primary tendencies in the activities of pro-Russian parties and public organizations in the context of Moscow's

${ }^{1}$ Mgr Mykola Turanskyi, Petro Sahaidachnyi National Army Academy of Ukraine (Lviv), https://orcid.org/0000-0003-0200-0998, e-mail: turanskijmikola@ukr.net
\end{abstract}


falsification of historical facts, the formation of negative opinions about Ukrainian leadership and political elites, discrediting European integration, as well as a rapprochement with NATO member states.

Key words: pro-Russian parties, NGOs, manipulation of public opinion, propaganda.

\section{Introduction}

In the twenty-first century there is a transformation to the paradigm of war - conventional warfare is being substituted by hybrid conflicts, which comprise non-military structures of the organisation, parties, and crowds of population, whose hands can do the so-called "dirty work." The pressure is on involvement of the civilian population, in order to inflict mass hysteria, and resistance to legitimate power. It is no coincidence the military doctrine of the Russian Federation (RF) says that a current military conflict implies "the complex employment of military force, political, economic, information and other non-military means implemented with widespread use of the protest and potential of the population plus the forces of special operations." (Military Doctrine of the Russian Federation, 2014).

Owing to the function of pro-Russian parties and non-governmental organisations, the Kremlin authorities were able to establish a bridgehead for an attack on Ukrainian independence. The idea to ruin the Ukrainian state was claimed by Y. Nikiforenko, chairman of the State Duma subcommittee on integration issues of Slavic people: "We are desperate not just for a separate part of Ukraine; our objective is to occupy it entirely, in order... to reunite it into a single state - The Union" (Holibard, 2015: 59). The Russian leadership considered the Crimea, primarily from the military-strategic point of view, as the best and sole base for the Russian Black Sea Fleet and the opportunity to deploy military units on the territory of The Peninsula keeping potential opponents in tension.

Russia had been conceiving the affiliation of Crimea from March 22, 1991, when the Crimean region was transformed into the Autonomous Republic of Crimea. The Russian diaspora along with numerous public organizations of pro-Russian orientation were the main ally in the peninsula. Special Forces of the Russian Federation employed them to provoke a negative Ukrainian attitude among the population, and to additionally create an atmosphere of dissatisfaction as well as formulating a public opinion concerning a better destiny in the affiliation with the RF. In Crimea, there was a large stratum of residents who called them- 
selves "Soviet people," they communicated exclusively in Russian and associated the Soviet past with the modern Russia. Doctor of Sociological sciences I. Ruschenko defines this social layer as the following: "'Soviet people" which is a residual identity as well as a specific Ukrainian marginality. These individuals still live in the past. Moreover, they do not recognise or criticise the present; they are rather hostile to the Ukrainian state" (Ruschenko 2015: 37).

Representatives of the diaspora established a dense network of agents fuelling propaganda. Under the slogans of preserving cultural traditions and maintaining relations with compatriots, they pursued a targeted information policy to develop an anti-Ukrainian outlook among the population of the peninsula. This was also facilitated by the dominance of Russian propaganda on Crimean local radio and television channels.

In coordination with the Moscow curators, the anti-Ukrainian individuals along with representatives of the former Communist Party leadership were appointed as heads of NGOs and various "cultural and educational" centres. The evolution and financial support of pro-Russian parties and organisations was provided by Moscow for almost two decades. Those political agents were used by the Kremlin as "soft power" during the capture of the peninsula. The activity of pro-Russian forces in the Crimea can be divided into several stages.

\section{Genesis of the "fifth column" in the Crimea (1992-1997)}

Preliminaries of the incorporation of the Crimea can be traced back to the collapse of the Soviet Union, when the Crimean issue became a barometer of the political climate. As soon as Ukraine proclaimed its independence, a Russian official delegation arrived in Kyiv (28.08.1991), threatening to reconsider the borders in the event of any detachment of Ukraine from Russia. Subsequently, the territorial claims of the Russian Federation to Ukraine were formalised by official decisions of the highest state bodies in Russia. On May 21, 1992, the Verkhovny Soviet of the Russian Federation (RF) adopted a resolution No. 2809-1 "On the Legal Assessment of the Decisions of the Supreme State Officials of the RF regarding the Change in the Status of the Crimea adopted in 1954". According to which the decree of the Presidium of the Verkhovny Soviet of the RF from February 51954 "On the transfer of the Crimean Region from the RF to the structure of the Ukrainian SSR" was recognised as not being legally valid since the moment of its adoption. The most acute 
problem was the question of the division of the Black Sea Fleet of the former USSR and the status of the city of Sevastopol.

Adopted in 1992, the Constitution of the Republic of Crimea (the name was determined by the Verkhovna Rada of the Crimean SSRR in February 1992) gave the local authorities extensive power. After that period Crimean leadership took the course of expanding its strength together with one-sided orientation towards the Kremlin. The fundamental political force of the Crimea in the first half of the 90's was the Republican Movement of the Crimea, which represented the Russian-speaking population and advocated pro-Russian views. Later it transformed into the Republican Party of Crimea (RPC). In 1993, representatives of the Republican Party of Crimea along with the People's Party of the Crimea united in the electoral bloc "Russia". As early as in January 1994, an envoy of "Russia" Yuriy Meshkov won the presidential elections in Crimea. Next, in spring, as a result of the victory in parliamentary elections, a delegate of "Russia" - Sergey Tsekov obtained the post of Chairman in the Supreme Council of the Crimea. Subsequently, the niche of the Republican Party of Crimea was occupied by the Union party, which advocated the notions of traditionally pro-Russian-minded circles. Moreover, they embraced rather strong positions in the Crimean Verkhovna Rada.

The internal political contradictions in Russia then prevented a decision on the Russian benefit of the Crimean question, although during the nineties it repeatedly acted as an obastacle to Ukrainian-Russian relations. In March 1995, by the special decision of the Verkhovna Rada of Ukraine, the Constitution of the Republic of Crimea was revoked, and the post of its President was revoked. However, in April 1995, the State Duma of Russia acted as the "guarantor" for conducting a referendum on the independence of the Crimea, but President Kuchma did not allow such developments: the provocative separatist manifestations were stopped thanks to the coordinated actions of the state leadership and the security and defence agencies. The attempts of the Crimean authorities to separate from Ukraine were defeated, and the status of the Autonomous Republic of Crimea (ARC) was enshrined in the Constitution of Ukraine on June 28, 1996. In 1998, a new Constitution of Autonomy was adopted, this event culminated in the period of the "war of sovereignty" between the Crimea and Ukraine.

Creation of the ARC Kyiv tried to localise the internal conflict between the Russian-speaking population and the Crimean Tatar repatriates. As at January 1, 1998, 262.8 thousand descendants of deported peoples had moved to the Crimea for permanent residence, including 259 thousand Crimean Tatars, 3.8 thousand Armenians, Bulgarians, Greeks 
and Germans (History of Crimea, 2015: 455). At the same time, the demographic situation also changed with the resettlement of military pensioners from Russia to the Crimea (especially to Sevastopol). The fostering of interethnic relations was promoted by defamatory materials on Tatars-repatriates of the newspaper "Krimskaya Pravda".

The hidden struggle against the Crimean Tatars began; this allegedly represented a great danger to Russian interests because of the obstruction of the intention to make Crimea a part of the Russian Federation. In particular, the newspaper "Krimskaya Pravda", which had thousands of readers among the inhabitants of the peninsula, formed a clearly negative image of the Crimean Tatars as well as the idea of their return and arrangement on the historical homeland. Among ways to solve the problems of the Crimean Tatar population, "Krimskaya Pravda" offered such solutions as the reunification of the old union state, or the support of the Crimean Tatars for the idea of joining the Crimea to the Russian Federation. However, there were openly anti-Tatar manifestations of Russian chauvinists. "The greatest strategic goal is the only Slavic state of Russia. And if we talk about a tactical goal, we will definitely fight for Russian national autonomy. Even if we do not achieve it, then we will not create Crimean Tatar national autonomy in the Crimea", proclaimed S. Shuvaynikov, who headed the "Congress of Russian Communities of the Crimea," before that he was the chairman of the Russian Party of the Crimea, which was banned in 1996. It was a locomotive of antiUkrainian political views; in particular it stood for the reunification of Ukraine and Russia into a single state (Shuvaynikov 1997).

Opponents of the "Ukrainian Crimea" were the left parties - the Communist Party of Ukraine (CPU), headed by Petro Symonenko, and the Progressive Socialist Party of Ukraine (PSPU) Natalia Vitrenko. They were financed from the Kremlin, lobbied for bills in favour of Russia, and headed the struggle against European integration of Ukraine. All the reasons for the discontent of these parties were built upon the failure to recognise Ukraine's independence from Moscow, with a somewhat nostalgic recollection of the Soviet Union. The assessment of this situation in December 1997 was given by President of Ukraine L. Kuchma: "Ukrainian Communists work for the Communist Party of Russia!" (Golybard 2015: 53). Even the report on the agenda of the 8th session of the Verkhovna Rada of the ARC included the issue of conducting a series of general Crimean referendum - granting Crimea the status of "Russian national autonomy", recognising Russian as a state language, and returning the Crimea to the Russian Federation (Voice of Ukraine, 1998: 7). From the Republican Movement of Crimea and the Republican 
Party of the Crimea, a public organisation "The Russian Community of Crimea" was founded. It's officially declared purpose was the restoration of the political, economic and cultural ties of the peninsula with the Russian Federation, lost in the destruction of the USSR, and in protecting Russia's sociocultural space in the Crimea. At the time of the annexation of the peninsula, the Russian community of Crimea comprised 29 regional organizations and had its own print agency, the Russian World newspaper, with a circulation of 35,000 copies. The distribution of funding by the Russian structures was a cause of discontent and provoked an aggravation of contradictions between the various pro-Russian forces of Crimea, primarily between the "Russian Society of the Crimea" and the "Russian Crimean Community" (History of Crimea, 2015: 466). Public organisations active in the interests of the Russian Federation in the Crimea during the 1990s were the Russian Community of Crimea, the Russian Society of Crimea, the Congress of Russian Communities of the Crimea (associated with the same Russian organisation), the Society of Russian Culture. Among these organisations, radical positions were occupied by the "Congress of the Russian People", headed by S. Shuvainikov, "Union of Soviet Officers", Crimean Human Rights Organization "Vera", "Russian Movement of Sevastopol", People's Front "SevastopolCrimea-Russia", and the recent financing was supplied from the Russian Funds, in particular from the construction of the Black Sea Fleet facilities of the Russian Federation (Nalyvaichenko 2009). The youth of the "Russian community of Crimea" became the "Russian Youth Centre of Crimea", created in 1997, which led the active work on the peninsula among young people, promoting Russian culture and educating Russian patriotism. After unsuccessful attempts to leave the ARC from Ukraine, the representatives of the Communist Party of Ukraine and the party "Labour Russia" together with representatives of the "Russian community of Crimea" organised protests for planning and conducting international exercises "Sea Breeze-1997" in Donuzlav. The Communists had warned the Country's President that joining NATO would be fatal for Ukraine, as it contradicts the interests of Russia, which is "our strategic partner!" (Holibard 1995)

During this period, the general idea of preserving the Russian development of the Crimea, strengthening of political, economic and cultural ties with the Russian Federation, attempts to win the special status of the Crimea and a separate presidency, and preventing the convergence of the Armed Forces of Ukraine with NATO, were common themes to all proRussian parties and societies. The curator of the pro-Russian force's Institute of Problems of the CIS was under the leadership of Konstantin 
Zatulin. It was the Zatulin team that initiated relevant organisations, movements and parties, when a significant part of the Russians generally loyal to the Ukrainian authorities, were happy with the illusions of the ethos "Crimean's".

\section{Consolidation of the Russification policy, including the destructive influence of "The Russian World" (1998-2003)}

During this period, the Kremlin government, headed by the newly elected President, Putin, used the strategy of a "hostile environment" where Russia defended the interests of not only its own citizens, but also became a shield in opposition to the dominance of American influence in the countries of the former USSR. Meanwhile, the concept of "The Russian World" was finally formed. The ideas of "fraternal people" and "Slavic unity", which are closely intertwined with linguistic identification, are spreading. This period was also characterised by an increase in anti-Western and anti-NATO rhetoric. From the Soviet era, the stereotype of NATO was formed as an aggressive enemy block, this stereotype continued in the 2000's. The manipulators were actively used against the Sea Breeze naval military exercises. The inhabitants of Crimea were convinced that the Russian Black Sea Fleet remained one of the biggest obstacles to Ukraine's accession to NATO. Nostalgia for the Soviet past found support among the Crimean population, especially the former Soviet troops, who were frightened by the possible loss of Sevastopol as a city of "Russian glory". This further deepened anti-NATO sentiment on the peninsula. For the education of young people in the spirit of the "Russian Peace", youth military patriotic camps were organised and conducted. From the second half of the 1990s, provocateurs cultivated the idea of ethnic expansion of Ukraine in the Crimea, forcible "Ukrainisation", and "Bandera occupation!" So, in 1999, on the Independence Day of Ukraine, a poster "Sevastopol - Russian City!" was put up on the Sevastopol Seaman's Club, and members of the National Bolshevik Party of Russia scattered leaflets "Kuchma - Suppress Sevastopol!" The Russian citizens carried out this political action, which were later transferred to the Russian side.

The Crimean Republican Committee of the Communist Party of Ukraine, the Sevastopol City Committee of the Communist Party of Ukraine and the Sevastopol City Committee of the PSPU, whose leaders O. Solomahin and E. Dubovik became leaders of the All-Crimean Asso- 
ciation "May 9" and the Sevastopol "Front against NATO", in one connection with the "Union of Soviet Officers" systematically conducted organisational work on the development of not only anti-NATO but antiUkrainian views among the population. They constantly used the "opinion leaders", political and religious personalities, athletes, and cultural figures to convey their message. Particularly powerful psychological pressure was felt by ordinary citizens of the peninsula during the events on the island of Tuzla. In one way with D. Rogozin, K. Zatulin, O. Dugin and other individuals who publicly supported Crimean separatism, there were organizations and groups operating in Ukraine such as the "Slavic Union", "Russian Bloc", "All-Union Union", "Eurasian Union of Youth", "Breakthrough", separate political parties - PSPU, CPU, Cossack pro-Russian formations, organisation of veterans, "Union of Soviet Officers", which in essence were all anti-Ukrainian. "They lead an outright anti-state activity, declare provocative slogans directed against independence. Freely and impersonally disseminate Anti-Ukrainian publications: newspapers, leaflets, brochures and books", reveals their activities Chairman of the Kiev Union of Armed Forces L. Hnatyuk (Hnatyuk, 2008). One of those especially concerned with the fate of the "Russian Crimea" was the former mayor of Moscow Yu. Luzhkov, who took the patronage of Sevastopol as the main centre of the consolidation of the "fifth column" in Ukraine. Not going to leave the Crimean Territories completely, because "Sevastopol should remain the main base of the Black Sea Fleet for all time," indeed, the Russian government invested heavily in the development of the city. In total, more than $\$ 3$ million came from the purse of the Russian Federation into the Sevastopol coffers (Korbut, 2005). In April 2001, Yuri Luzhkov declared open the Russian Cultural Centre (RCC), created by the Moscow-Crimean Economic and Humanitarian Relations Foundation. Among the activities in this centre, priority was given to preserving and developing the Russian language and Russian culture in the ARC, strengthening cultural, business and spiritual ties with Russia, preserving and enhancing Russian national traditions. Affiliates of the RCC appear in the cities of Alushta, Bakhchysaray, Dzhankoy, Yalta, Evpatoria, Feodosia, Kerch, where, in the guise of humanitarian assistance to compatriots, solemn events were held in honour of the Day of Russia, the reunification of the Crimea with Russia, etc. The RCC distributed books and textbooks that were sent from Moscow to the local libraries and schools. The Library Department, which had the widest list of Russian newspapers and magazines, organised working groups with readers in order to form Russian consciousness and promote Russian language and culture. A separate area of youth 
work was the organisation of youth military patriotic camps, such as Donuzlav-anti-NATO. Together with the Simferopol and the Crimean diocese, a celebration of religious holidays was organised, which was held together with the Crimean Cossack Union. The RCC TV program daily produced the "Curanty" program, which promoted the activities of the Russian government, the Moscow-Crimean Foundation. Also, there was a close cooperation with branches of Russian universities, especially with the Black Sea Branch of the Moscow State University in Sevastopol. There were about 10 branches of Russian science and education establishments in the city and they organised dozens of conferences, symposiums and meetings. According to Y. Luzhkov, such powerful cultural-psychological and informational actions made it impossible for the local population to become accustomed to Ukraine, keeping it ready for an anti-Ukrainian referendum (Losev 1999). A few years later, for the practical implementation of the "Russian World" project, the Ministry of Science and Education and the Ministry of Foreign Affairs of the Russian Federation was supported by the same fund. During 2008-2012, this fund created more than 10 Russian centres, the first of which was opened in the Crimea - in Simferopol and Sevastopol. The object of attacks on pro-Russian public associations was the Crimean Tatar population. According to the 2001 census, 2,024,000 people were living in the Crimea; of these, Russians accounted for $58 \%$ of Ukrainian, 24\%, Crimean Tatars - 12\% (History of Crimea, 2015: 430). Although the RCC positioned one of its programmatic tasks to strengthen interethnic relations on the peninsula, in real life everything was happening in exactly the opposite. Russian mass media used the intimidation of the spread of anti-Russian "Islamist" groups as the most effective method of psychological influence. Activists in the Crimea and the Cossack movement provoked clashes with Crimean Tatar activists in the cities of Sudak, Bakhchisarai, Feodosiya. In general, the actions of Moscow's psychological pressure highlighted a key importance: with their help, the Crimeans were accustomed to the idea that the country would be plunged into chaos, and only Russia's intervention could save, if not the whole country, then, at least, Crimea. As the proper state information policy was not carried out, the inhabitants of the peninsula were active consumers of the Russian information product. For example, aggressive anti-Ukrainian newspapers "Rusichi", "Sevastopolskaya Pravda", "Russkiy Sevastopol", "Russiy Krym", "Rodina", "Posledniy Bastion" are published in the newspaper "Flag Rodiny" in the newspaper of the Black Sea Fleet. On the basis of "Eurasian" ideas, an anti-Ukrainian and anti-Western ideology was actively promoted, which created the foundations for the activity 
of frankly anti-Ukrainian movements such as the party "Russian Unity", the Cossack brotherhood "Unity", the branches of the Russian organization "The Essence of Time", and the Eurasian Youth Union.

One of the most radical public organizations was the "Breakthrough", whose activists, as a youth wing, attracted the "People's Opposition" N. Vitrenko. This public association carried out political shows and attracted the attention of the media. The "Breakthrough" leader, Alexei Dobrinin, deported to Russia for anti-Ukrainian activities in June 2006, scared the Russian-speaking population with an increase in the autonomy of social and ethnic tension, provoked by the activity of the Tatar national radicalism, as the Mejlis's leaders were aiming to create an independent Islamic state. The leader of the Crimean Tatars, M. Dzhamilev, revealed the grounds for such views: "They set their task to separate the Crimean Tatars, remove the Head of the Mejlis, and to include proRussian-oriented activists from Russia..." (Dzhemilev 2011).

\section{Fighting the "Orange Threat" and Activating Advocacy (2004-2009)}

The "Orange Revolution" in 2004 was seriously frightened by the Russian leadership, provoking its intense preparation for the hybrid war (Magda, 2015: 19). The election of President V. Yushchenko was interpreted as coming to power of nationalists, "Bandera" and "American invaders". Speaking at the St. Petersburg and Moscow State University, Socialist Speaker V. Lytvyn, Chairman of the Verkhovna Rada of Ukraine, emphasized the need for cooperation with the Russian Federation (Voice of Ukraine, 2005). At that time, the Russian intelligence services had already formed an extensive network of anti-Ukrainian organisations within the peninsula, controlled by Russian agents, a variety of public associations focused on the idea of the "Russian World", paramilitary education (Cossack formation, fighting clubs). For activities in social networks, the FSB in 2006 created the "18th Centre". The propaganda campaign deployed by the pro-Russian forces of the Crimea with the support of the secret services contained traditional means of disinformation, falsification and distortion of facts.

The main task of the Moscow manipulators of the Yushchenko presidency was at all costs to prevent Ukraine from joining NATO, since then all plans to capture Ukrainian territories would collapse (Ruschenko 2015: 44). For political intelligence, the formation of groups of supporters and the creation of agents of influence with their support in a broad 
campaign to counteract NATO, the Kremlin effectively targeted the Communists and progressive socialists. On the pages of the Crimean press there were articles directed against the North Atlantic Alliance. Cossack formations took an active part in anti-NATO performances. The purpose of such protests was to prevent the conduct of joint UkrainianAmerican exercises Sea Breeze.

When the American ship "Adventure" moored in the port of Feodosia in the spring of 2006, Russian propagandists perceived this fact as an attempt to deploy a NATO base in the Crimea. Cossack forces who set up a tented camp, subsequently joined supporters of pro-Russian party and non-governmental organisations.

Protesters were demanding a halt to the entrance of NATO troops in Feodosia. A representative of the Russian State Duma K. Zatulin supported the rally against the Alliance; consequently he was banned to enter the Crimea. The Crimean Communists even held a so-called "AllCrimean People's Referendum on Ukraine's membership to NATO". One of the organisers of this action was People's Commissar L. Grach, who believed that stability on the peninsula undermined the desire of the political leadership and, above all, the President to break irrevocably with the Soviet past. The former Speaker of the Verkhovna Rada of the ARC "remained one of the recognized leaders, thanks to which Crimea holds the" red belt "on the political map of Ukraine," "Gazeta 2000" informed (Vavilova, 2007).

Youth Cossack organizations are the Orthodox Crimean Youth Association "Zvezda" under the Union of Cossacks of the Crimea, Feodosia School of Jur, Crimean Cossack Cadet Corps under the leadership of Ataman A. Kuslyvy, that received the support of the General Consulate of Russia and the agency "Russotrudnichestvo" in the city of Simferopol, insisted on prohibition of the joint US-Ukrainian military exercises in the Crimea.

With the anti-NATO content, Donuzlav-Crimea-anti-NATO hosted military patriotic camps, the first of which started operating in 2007. Those blatantly pro-Russian camps operated under the patronage of the "Russian Unity" movement. Since then, such youth assemblies have taken place every year, having been assisted by the People's Deputies of the ARC from the left wing forces, the Cossacks (the Union of Cossacks of the Crimea, the Black Sea Cossack hundreds, and Patriots of Sevastopol) as well as pro-Russian NGOs and representatives of the Russian Federation in the Crimea. The structures of the Union of Cossacks of the Crimea were conducted by sports, tourist and military-patriotic camps for youth. Subsequently, work with youth was expanding to the organi- 
zation of the Caucasian camp "Tavrida-Sech", which was supervised by the Tavria Cossack Military Society and the Crimean Republican Public Organization "Tavria Union". The deputy of the Bakhchisaray City Council, the Chief of the Union of Cossacks of the Crimea, S. Yurchenko, was elected Camp Commandant.

Pro-Russian youth organizations "The Breakthrough", the Eurasian Youth Union (banned in Ukraine for anti-state activities), the Russian youth movement acted in the wake of the left-wing parties and radical public associations, including the People's Front "Sevastopol-CrimeaRussia", the Russian community of Sevastopol, Russian community of the Crimea. They jointly delivered pickets and rallies under Russian banners and flags: in 2007, the "Breakthrough" members launched the campaign "A Russian Flag In Every Window!" And in 2008, protested against the law to duplicate films in the Ukrainian language. In general, the linguistic issue was used extensively by the pro-Russian forces to create not only cultural but also ethnic-identity contradictions. Chairman of the Verkhovna Rada of the ARC V. Konstantinov (member of the Party of Regions) said that the Verkhovna Rada of Crimea always initiated political and cultural actions in support of the Russian language, and this should be continued. The Union of Russian Culture "Rus" clearly fabricated facts about the general reduction in the ARC of Russian schools (by 89\%) and cultural institutions, in particular Russian theatres (by 70\%), not to mention the anti-Ukrainian actions of the Breakthrough and the Popular Front "Sevastopol-Krym-Russia". The propaganda war was primarily directed at the intensification of pro-Russian movements and the creation of an atmosphere of negative attitude towards the enemy's cultural heritage. By the dissemination of ideas of the "Russian Peace," the Russian manipulators influenced so-called forcible "Ukrainisation" in order to provoke national and religious conflicts. For example, in 2009 in the Crimea there were only 7 Ukrainian schools, only $7.3 \%$ of the Crimean students studied in Ukrainian, however, according to the Razumkov Centre, $75.2 \%$ of Crimean residents believed that they were undergoing forced "Ukrainisation". The implementation of a large-scale cultural propaganda campaign aimed at destroying the polyethnic culture of the Crimea and replacing it with the re-transmission of the neoImperial discourse was also observed in the information policy on the peninsula, when the broadcasting of the Crimean State Television and Radio Broadcasting Company "Twenty-four times" provided twenty times more broadcasts in Russian than in Ukrainian and almost nine times more than in the Crimean Tatar language (Voice of Crimea, 1999). 
Psychological operations are the most efficient in conditions when individuals unknowingly perceive or gain information. The danger of a domestic approach to cultural conflicts is that an average person is easily enthralled by the external hatred and supposed "superiority" of his culture. The high level of confidence among the Russian-speaking population of the Crimea, information received from the Russian channels, the scarcity of Ukrainian sources of information increased the number of supporters of Putin's policy at the time of the annexation arrangement of the Crimea. Anti-Ukrainian themes in the ARC were presented at a convenient moment (for example, during the "orange revolution") and were superimposed on well-known psychological technology - a spiral of silence. In 2006, about 70 Russian organizations operated in Ukraine, while in Russia, "we are watching the increase of anti-Ukrainian propaganda in the media of the Russian Federation and the growth of Ukrainophobia in society. Analysing the biased appearances of various Russian politicians in addressing Ukraine, the Ukrainian language, the statement about the oppression of the Russian-speaking population in Ukraine, and the absence of Russian media in Ukraine, we can conclude that anti-Ukrainian policy in Russia has been raised to the rank of state." (The appeal of the head of the republican national-cultural centre of Ukrainians of Bashkortostan to V. Putin, 2006). In 2008, comprehensive measures preparing acts of armed aggression against Ukraine was initiated. One of the leaders of the People's Front "Sevastopol-Crimea-Russia" S. Klyuyev urged the Crimean parliament to adopt the Declaration on the reunification of the Crimea with Russia and to declare the peninsula to be a territorial unit under the jurisdiction of the Russian Federation. He was corroborated by panels of the coalition "Russian Unity" and in May 2008 Y. Luzhkov said that Sevastopol should be returned to the Russian Federation.

In October 2008, the "independence" of the Georgian autonomous republics of South Ossetia and Abkhazia inspired the pro-Russian forces in the Crimea. (History of the Crimea, 2015: 468). The leader of the Crimean Tatars, M. Dzhamilev, warned of the danger from the RF: "The recent Russian-Georgian war showed the whole degree of "respect" for territorial integrity. One of the reasons for the invasion of Georgia was that there was a violation of the rights of nationalities. That is to say Russia acted as if to protect its citizens. This situation is similar in the Crimea! On one hand, Putin allegedly declares that there are no territorial claims to Ukraine; on the other hand, he says it is necessary to respect the rights of the Russians. But once he will say the rights of the Russians are violated" (Dzhemilev 2010). In October 2009, on the initiative of the 
Russian community of Crimea and the Civic Asset of Crimea, the AllCrimean Social-Political Movement "Russian Unity" was founded with the support of more than thirty Crimean NGOs and political parties. And in August 2010 from the political party "Avangard" a party "Russian Unity" was formed, headed by S. Aksenov, a native of the criminal group "Salem", who from 2008 was a member of the "Russian community of Crimea". In the end, the criminalised structures of the Party of Regions and the Communist Party of Ukraine played a key role in the Russian penetration of the peninsula, with the solid assistance of Russian special services. Therefore, it was not accidental that annexation coordinated with the appointment of the head of the Crimean parliament V. Konstantinov, together with the head of the Crimea - S. Aksenov. The support of the party "Russian Unity" was received by the "Russian Youth Centre of the Crimea", which at the end of 2009 changed its name to "Young for Russian Unity". The organisation positioned itself as the only movement that showed patronage to the Crimean youth. The proRussian forces in the Crimea intensively promoted the idea of Ukraine joining the Customs Union, opposed the course of Ukraine's cooperation with NATO as well as European integration, and actively collaborated with the Crimean diocese of the Ukrainian Orthodox Church under the Moscow Patriarchate.

\section{Exploitation of the language factor in anti-Ukrainian activities (2010-2013)}

As soon as V. Yanukovych came to power, an extensive "sovietisation" emerged in the Crimea: Soviet themed days were loudly celebrated, red banners were hung, and Soviet films were broadcast. By closely monitoring the course of the situation in the ARC, Russian intelligence services cleverly employed public associations and parties to establish favourable models for the Kremlin's behaviour. The Russian invasion was preceded by an active propaganda campaign, various scenarios of destabilization of social life were designed, and unresolved problems of the Crimean Tatar population were used. Thus, A. Mogilev, who headed Yanukovych's electoral headquarters in the Crimea, was publicly accused of stirring up inter-ethnic hostility against the Crimean Tatars.

A rapid pace on the peninsula is the politicisation of Russian identity. The use of language factor was the most convenient and effective for the Kremlin. It was used by Russia as the main reason for aggression, 
explaining it was needed to protect Russian-speaking citizens in Crimea. It was thanks to an information campaign that the field was thoroughly prepared in advance, Russia so easily annexed the Ukrainian Crimea. The calls to leave the "compatriots" that were beyond Russian borders began to sound. The program of Russian nationalists in the Crimea included requirements for the constitutional consolidation of the status of Russian as a state or official; strengthening of integration relations with the Russian Federation and the CIS, withdrawal from cooperation with the West; the introduction of dual citizenship (both Ukrainian and Russian); a common information space (Nalyvaychenko 2010). Signing on April 27, 2010 "Agreements between Ukraine and the Russian Federation on the issues of the Black Sea Fleet's stay in the territory of Ukraine" made it possible to strengthen the pro-Russian component of the Crimean political community and increased the threat of drawing the peninsula into the orbit of Russian interests.

After the elections to the Verkhovna Rada of Ukraine in 2012, a conflict broke out between the political parties "Russian Block" and "Russian Unity". Previously, there was a tacit agreement on demarcation of territories: "Russian Block" acted within Sevastopol, and "Russian Unity" - within the entire peninsula. As a result of the conflict between the leader of the "Russian community of Crimea", the chairman of the Crimean Coordination Council of organisations of Russian compatriots (CRRS) S. Tsekov and the heads of the territorial branches of the "Russian community of Crimea," the organisation split into two distinct entities. The faction of the split "Russian community of Crimea" led by O. Melnykov declared his adherence to the Crimean Republican branch of the Russian Bloc and criticised the "Russian unity," whose deputy head was another contender for leadership in the "Russian community of the Crimea" - S. Tsekov. In addition, Tsekov was accused of liquidating the party "Russian Block" in order to remove a competitor for the party "Russian Unity" in the territory of Sevastopol. For its part, the Crimean branch of the Russian Bloc, headed by K. Belov (https://informnapalm.org/ua/ prorosijski-organizatsiyi-[accessed, December 5, 2018]), intensified its activity. Such squabbles between the leaders of different political forces were a common occurrence. The struggle for the monetary sustainment of the Russian "sponsors", the futile ambitions to become "the first among equal", an attempt to prove that it was a very organization to lead the population was a characteristic feature of the majority of pro-Russian public associations. 


\section{Radicalisation of pro-Russian NGOs and arrangement of a bridgehead for Russian occupation (the second half of 2013 - March 2014)}

In terms of an active phase of the Russian aggression against Ukraine in the spring of 2014, there occurred a radicalisation of promoters of the "Russian Peace". The period was characterised by a powerful increase in proRussian mood. There was a consolidation of the pro-Russian forces, political and organisational preconditions were set up for the occupation of the peninsula, arranged by the so-called "Self-defence detachments" to supposedly support public order. Representatives of the acting authorities of the Crimea were widely broadcast to highlight the rejection of the Crimean events in Kyiv. One of the "anti-Maidan" advocates turned out to be a deputy of the Verkhovna Rada of the Crimea, Y. Fiks, reported on the intensive formation of the Crimean volunteer detachments. "The Russian community of Sevastopol" appealed to Russia to protect the Russians: "In the light of what is happening, the Russian population is at risk of genocide." Russian news emphasised that Sevastopol was the main city of resistance to Ukrainian nationalists. K. Makhnav, the Ataman of the Coordinating Council of the Cossack Communities at the Bloc of Sevastopol, declared: "We cannot allow to enter those with whom we fought - fascists, followers of Bandera." Leader of the NGO "Front against NATO", the second-ranking captain in the reserve Ye. Dubovik in an interview with the "News" of the Russian "First Channel" states: “ ...Neo-Nazis seized power, Kiev was loyal to loot, shouts about the Communists- on gallows, Russians-on knives, that is because Nazism captured the power..." (https://informnapalm.org/ ua/prorosijski-organizatsiyi, access December 5, 2018). An active participant of the Black Hundred Internet Forums and the head of the fund named after General Kutepov M. Ganja called for donations to support the media portal "Second Front".

Starting in December 2013, Russian TV channels openly talked about the possibility of a split in Ukraine, the rumours concerning an annexation of the Crimea were being distributed since February 20, 2014, when the statement of the Speaker of the Verkhovna Rada of the ARC V. Konstantinov that the Crimea could separate from Ukraine was announced. Chairman of the Council of Ministers of the ARC A. Mogilev, constantly contacted by emissaries of the Kremlin, left for consultations in Moscow. The Crimean parliament recognised the "Freedom" party as a neo-Nazi party and prohibited its activities on the territory of the peninsula. The situation on the peninsula made headlines in the Russian media. Russia's television in any effort did their best to prove the 
legality of the Russian military groups' entry the Crimea. That type of propaganda was believed by the Crimean population, which was the primary goal of Moscow, according to a deliberate plan, February 20, 2014, saw rallies in cities assembled accordingly. Sevastopol and Simferopol were requiring an affiliation with Russia and a referendum on the status of the ARC. To participate in those events on the peninsula, certain sorts of Russian citizens were especially imported such as sportsmen, security guards, former servicemen who played the role of "indignant Crimeans" and provoked conflicts. Cossack detachments were quickly mobilized, in which, along with members of the Union of Cossacks of the Crimea, there were units of the Tern Cossack Army (RF). Members of the biker club "Night Wolves", paid at the expense of budget funds of the RF, were in the so-called Crimean self-defence detachments: in February 2014, they patrolled the roads and took part in capturing the Ukrainian Navy's headquarters in Sevastopol.

Concurrently, Russian propaganda created a positive image for agents of the Crimean pseudo-leadership - V. Konstantinov. S. Aksonova, O. Chaly. Notably, in Sevastopol, which was titled "the most Russian city of Ukraine", an entrepreneur O. Chaly being a citizen of the Russian Federation, was elected the "People's Chairman".

On February 26, comments of deputies of the Federation Council and the State Duma of the Russian Federation regarding the protection of the Russians in the Crimea appeared; an official delegation of the State Duma, headed by the Chairman of the Committee on the CIS, Eurasian integration and ties with compatriots L. Slutsky, arrived in the peninsula. Additionally, the head of "the Fair Russia" party S. Mironov got to Crimea and subsequently justified the Russian presence: "The nationalists came to power today. People who profess fascist ideology, people who will necessarily force Russian people not to speak Russian will come. We cannot blindly observe what is happening in Ukraine with our brothers, our Russians" (Mezhygirsky, 2014). V.D. Konstantinov met with deputies of the State Duma. Under the walls of the Crimean parliament, a pro-Russian rally, where the majority of people were members of the pro-Russian organizations, the Crimean Front, the People's Liberation Movement, the Tauride Unity, and the skeleton of the local Cossacks, took place. Relying on a powerful multi-year informational and psychological effect on the residents, in the early stages of aggression, they managed to substantially disorient the people of the Crimea.

The fact of vigorous participation in the events of the "Crimean Spring" of public-political movements and parties of pro-Russian orientation that operated on the peninsula is indisputable. 


\section{Conclusion}

The analysis of publications in the periodicals, analytical resources along with scholarly research on the historical preconditions of events on the Crimean Peninsula in 2014 provides grounds to argue that throughout the period of Ukraine's independence, the Russian Federation supported anti-Ukrainian sentiment among the Russian-speaking population of Crimea, intensively employing NGOs of pro-Russian orientation.

A dynamic Russification policy in the Crimea was executed by local authorities throughout the years of independence, having generated the basis for anti-Ukrainian attitudes including a favourable environment for function of Russian special services. The Russian Federation vigorously monitored the tensions and situation in the Crimea and guided it, firstly, establishing a numerous pro-Russian public associations, secondly, conducting a massive propaganda campaign on "legitimate rights" of the Russian Federation to the Crimea, exclusively to Sevastopol.

The aid of psycho-informational technologies enabled the transformation of the population's mood on the peninsula, where stereotypes of the past, misinformation, manipulation of consciousness, the formation of a negative image of Ukraine contributed to the loss of the national identity of the Crimean people, tolerant attitude to other ethnic groups, led to an increase in anti-Ukrainian sentiments and rejection of Ukraine's European choice. Over 20 years there were cultivated views on "ethnic expansion", the ban of the Russian language, "Bandera's occupation" in the Crimea. The Ukrainian authorities were not concerned with the demand of the peninsula population for Russian media, which eventually led to destructive influence on the consciousness of citizens, subsequently; the converted consciousness entailed a deterioration of attitudes towards the state itself.

Pro-Russian agencies together with parties which widely operated in the Crimea and whose number exceeded three dozen, endeavored to shape an idea of their own peculiarities in the residents of the peninsula, their belonging to the "Russian world", as well as the overwhelming majority of Russians in the autonomy executed psychological pressure on other ethnic groups, implementing political and nationalistic methods of impact.

A huge mistake of the power bodies of Ukraine was the fact that they did not pay enough attention to the vivid manifestations of Russian propaganda and the attempts at psychological influence on Ukrainian citizens. In the light of the upcoming parliamentary and presidential elections in 2019, the danger of stepping on the same rake is very likely; it is 
enough to see the efforts of the "Opposition Bloc" to keep the eastern and southern regions in their field of activity at any cost.

\section{List of referencies}

Military Doctrine of the Russian Federation. http://www.rg.ru/2014/12/30/doktrinadok.htm [access 5 December 2018].

Golybard E., 2015, The criminal hand of Moscow in Ukraine. A fragment of the modern chronicle (1994 - early 2015). Facts, Faces. Comments - K .: Ukrainian Priority.

Ruschenko I., 2015, Russian-Ukrainian hybrid war: a sociologist's view. - Kharkiv: Vivat.

History of the Crimea in questions and answers. Back Editor V. Smolij. - K .: Scientific Opinion, 2015.

Interview with the Head of the SSU V. Nalyvaichenko, Komsomolskaya Pravda in Ukraine, February 18, 2009.

Shuvaynikov S., 1997, We asked for help to the Congress of Russian Communities, Voice of Ukraine, November 1.

There is a great desire to work, Voice of Ukraine, February 6, 1998.

Hnatyuk L., 2008, Appeal of the Head of the Kiev Organization of the Union of Officers to the President of Ukraine V. Yushchenko, Ukrainian word, January 2-25.

Korbut A., 2005, Kiev v. Sevastopol, Military Industrial Courier, December 28.

Losev I., 1999, Sevastopol: Shard of Russian Culture in Ukraine, The Voice of Crimea, December 17.

Magda Ye.V. Hybrid War: Survive and Defeat. - Kharkiv: Vivat, 2015. http://argumentua.com/novosti/spetssluzhby-rossii-razrabotali-plan-po-destabilizatsii- situatsii-v-krymu-mustafa-dzhemilev [access 5 December 2018].

Statement by the parliamentary faction of the Socialist Party of Ukraine on the need for cooperation with the Russian Federation, Voice of Ukraine, January 14, 2005.

Vavilova E., Crimean Nationalist, Gazeta 2000, December 28, 2007.Voice of Crimea, February 19, 1999.

Nalyvaichenko V., The letter of the Chairman of the Council of "Our Ukraine" party V.Nalyvaychenko to the parliamentarians, Young Ukraine, October 2, 2010.

Mezhygirsky A., How Russian Media Encouraged Separatism in the Crimea, 2014 http://osvita.mediasapiens.ua/material/27927 [access December 5, 2018].

https://informnapalm.org/ua/prorosijski-organizatsiyi-ta-klyuchovi-osoby-yaki-velypidryvnu-diyalnist-u-krymu/ [access 5 December 2018].

\section{Rola prorosyjskich partii i organizacji w aneksji Krymu przez Federację Rosyjską}

\section{Streszczenie}

W aneksji Krymu przez Rosję istotną rolę odegrały prorosyjskie partie i ruchy, które Kreml za pośrednictwem swoich agencji wywiadowczych założył i finansowo wspierał przez ponad dwadzieścia lat. Na Krymie, gdzie władze Kremla stworzyły sieć agencji, najwyraźniej widać rolę działalności dywersyjnej, która była i jest ważnym kierunkiem rosyjskiej polityki. Komponent propagandowy był jednym $\mathrm{z}$ kluczowych aspektów 
w rosyjskiej inkorporacji Krymu nie tylko jako uzupełnienie zbrojnej agresji, ale także niezależny element wojny hybrydowej przeciwko Ukrainie. Presja informacyjna i psychologiczna ze strony Moskwy za pośrednictwem mediów i Internetu dla ludzi zarówno na Ukrainie, jak w Rosji miała niespotykaną dotąd w okresie postsowieckim intensywność.

Celem autora było pokazanie działalności partii i organizacji prorosyjskich w interesie obcego państwa, ich psychologicznego i informacyjnego wpływu na społeczeństwo Krymu podczas fazy utajonej konfliktu oraz podczas „Krymskiej wiosny”. Pomimo swej istotności problem nie doczekał się dotąd szerszych badań. Opracowania poświęcone prognozowaniu rozwoju wydarzeń w zakresie stosowania hybrydowych technologii wojennych i analizie stanu bezpieczeństwa informacji oraz przeciwdziałaniu informacjom i operacjom psychologicznym uwzględniają głównie polityczne aspekty wpływu informacyjnego. Poza namysłem badaczy pozostaje czynnik społeczny podkreślający technologię propagandy stosowanej podczas wojny hybrydowej.

Nowością naukową opracowania jest badanie głównych trendów działalności prorosyjskich partii i organizacji publicznych w kontekście fałszowania przez Moskwę faktów historycznych, tworzenia negatywnej opinii o ukraińskich przywódcach i elitach politycznych, zdyskredytowania integracji Ukrainy z UE i NATO.

Słowa kluczowe: partie prorosyjskie, organizacje publiczne, manipulowanie opinią publiczną, propaganda 